\title{
The multi-ligand somatostatin analogue SOM230 inhibits ACTH secretion by cultured human corticotroph adenomas via somatostatin receptor type 5
}

Leo J Hofland, Joost van der Hoek, Richard Feelders, Maarten O van Aken ${ }^{1}$, Peter M van Koetsveld, Marlijn Waaijers, Diana Sprij-Mooij, Christian Bruns ${ }^{2}$, Gisbert Weckbecker ${ }^{2}$, Wouter W de Herder, Albert Beckers ${ }^{3}$ and Steven W J Lamberts ${ }^{1}$

Department of Internal Medicine, Section of Endocrinology, Erasmus Medical Centre, Dr Molewaterplein 40, 3015 GD Rotterdam, The Netherlands, ${ }^{1}$ Department of Endocrinology and Metabolism, Leiden University Medical Centre, Leiden, The Netherlands, ${ }^{2}$ Biomedical Research, Novartis Pharma AG, Basel, CH-4002, Switzerland and ${ }^{3}$ Service d'Endocrinologie, CHU de Liege, Domaine Universitaire du Sart-Tilman, Liege 4000, Belgium

(Correspondence should be addressed to L J Hofland, Department of Internal Medicine, Section Endocrinology, Room Ee585c, Erasmus MC, Dr Molewaterplein 50, 3015 GE Rotterdam, The Netherlands; Email: 1.hofland@erasmusmc.nl)

\begin{abstract}
Objective: Currently, there is no effective medical treatment for patients with pituitary-dependent Cushing's disease. A novel somatostatin (SS) analogue, named SOM230, with high binding affinity to SS receptor subtypes $\mathrm{sst}_{1}, \mathrm{sst}_{2}, \mathrm{sst}_{3}$ and $\mathrm{sst}_{5}$ was recently introduced. We compared the in vitro effects of the sst ${ }_{2}$-preferring SS analogue octreotide (OCT) and the multi-ligand SOM230 on ACTH release by human and mouse corticotroph tumour cells.

Methods: By quantitative RT-PCR the sst subtype expression level was determined in human corticotroph adenomas. In vitro, the inhibitory effect of OCT and SOM230 on ACTH release by dispersed human corticotroph adenoma cells and mouse AtT20 corticotroph adenoma cells was determined. In addition, the influence of dexamethasone on the responsiveness to OCT and SOM230 was studied. Results: Corticotroph adenomas expressed predominantly sst $_{5}$ mRNA (six out of six adenomas), whereas sst $_{2}$ mRNA expression was detected at significantly lower levels. In a $72 \mathrm{~h}$ incubation with $10 \mathrm{nmol} / \mathrm{l}$ SOM230, ACTH release was inhibited in three out of five cultures (range -30 to $-40 \%)$. Ten nmol/l OCT slightly inhibited ACTH release in only one of five cultures $(-28 \%)$. In AtT20 cells, expressing $\mathrm{sst}_{2}, \mathrm{sst}_{3}$ and $\mathrm{sst}_{5}$, SOM230 inhibited ACTH secretion with high potency $\left(\mathrm{IC}_{50} 0.2 \mathrm{nmol} / \mathrm{l}\right)$. Dexamethasone $(10 \mathrm{nmol} / \mathrm{l})$ pre-treatment did not influence the sensitivity of the cells to the inhibitory effect of SOM230, suggesting that $\mathrm{sst}_{5}$ is relatively resistant to negative control by glucocorticoids.

Conclusions: The selective expression of sst $_{5}$ receptors in corticotroph adenomas and the preferential inhibition of ACTH release by human corticotroph adenoma cells by SOM230 in vitro, suggest that SOM230 may have potential in the treatment of patients with pituitary-dependent Cushing's disease.
\end{abstract}

European Journal of Endocrinology 152 645-654

\section{Introduction}

The first choice of treatment of patients with pituitarydependent Cushing's disease is surgery. If surgery fails, radiotherapy, alone or in combination with steroidogenic inhibitors, may be used $(1,2)$. These secondary options are primarily due to the absence of an effective medical treatment option $(3,4)$. Some preliminary data suggest a potential use of dopamine agonists, alone or in combination with ketoconazole, in selected cases of Cushing's disease or Nelson's syndrome (2). The expression of somatostatin (SS) receptors (sst) in adrenocorticotrophin (ACTH)-secreting pituitary adenomas has been studied in vivo and in vitro. In vivo, none of a series of eight corticotroph microadenomas showed an increased uptake of ${ }^{111}$ In-DTPA-labelled octreotide (OCT), whereas sst scintigraphy was positive in two invasive ACTH-secreting macroadenomas and two cases of Nelson's tumours (5). The current generation of sst $_{2}$-preferential SS analogues have no suppressive effect on ACTH level in patients with untreated Cushing's disease, who have elevated cortisol levels (6). However, the SS analogue OCT suppressed pathological ACTH release in patients with Nelson's syndrome and ACTH and cortisol secretion in patients with Cushing's syndrome caused by ectopic ACTH secretion (7-9). Overall, these data suggest that in corticotroph adenomas of untreated patients with Cushing's disease levels of sst $_{2}$, one of the five known sst subtypes to which OCT binds preferentially, are low, and that this receptor 
subtype may be downregulated when circulating cortisol levels are high. The fact that ectopic ACTH-secreting tumours express sufficient sst numbers allowing their in vivo visualization by sst scintigraphy and responsiveness to OCT, even in the presence of a high cortisol level, can be explained by their relative resistance to glucocorticoids, compared with corticotroph adenomas (10). Additional in vitro evidence for a sst downregulation by hypercortisolaemia comes from studies using primary cultures of human corticotroph adenomas, in which it was shown that glucocorticoids downregulated the response of corticotrophin-releasing hormone (CRH)-induced ACTH secretion to OCT (11). Little is know yet about the quantitative expression levels of the five sst subtypes $\left(\mathrm{sst}_{1-5}\right)$ in normal and tumoral corticotroph cells. By double-labelling in situ hybridization analysis for $\mathrm{sst}_{2}$ and $\mathrm{sst}_{5}$ mRNA, Day et al. (12) showed that normal rat corticotrophs expressed preferentially sst ${ }_{5}$ mRNA. In a few selected cases expression of sst subtype mRNA transcripts was studied in human corticotroph adenomas. In these studies it was found that the highest frequency of expression of sst mRNA transcripts was found for $\mathrm{sst}_{2}$ and $\mathrm{sst}_{5}$, and to a lesser extent sst 1 (13-16). Although sst $_{2}$ mRNA can be found in corticotroph adenomas, their levels of expression are apparently low since OCT has no effect on ACTH secretion in patients with pituitary-dependent Cushing's disease. However, at present the role of the other frequently expressed sst subtype, sst $_{5}$, on ACTH secretion by corticotroph adenoma cells is unclear.

Recently, a novel multi-ligand SS analogue, SOM230, has been synthesized. Compared with OCT, SOM230 has a 30-, 5- and 40-times higher binding affinity for sst $_{1}$, sst $_{3}$ and sst ${ }_{5}$ receptors respectively, and 2.5-times lower affinity for $\operatorname{sst}_{2}$ (17). The very high affinity of this SS analogue for sst $_{5}$ probably forms the basis for the higher potency of SOM230 in reducing insulinlike growth factor-I concentrations in rats, primates and dogs (18). Moreover, the very favourable elimin-

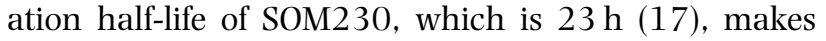
this novel compound suitable for clinical application as well.

The present study was carried out to further explore the potential functional significance of sst subtypes expressed in human corticotroph adenomas. We evaluated the effect of the SS analogue SOM230 on ACTH secretion by primary cultures of human corticotroph adenomas and mouse AtT20 corticotroph tumour cells.

\section{Materials and methods}

\section{Patients}

Pituitary tumour samples were obtained by transsphenoidal operation from 11 patients with Cushing's disease due a corticotroph adenoma as described in detail previously (19). ACTH-dependent hypercortisolism was biochemically established by the absence of cortisol diurnal rhythm, an increased $24 \mathrm{~h}$ free cortisol excretion, insufficient suppression of plasma cortisol concentrations after administration of $1 \mathrm{mg}$ dexamethasone (DEX) and normal to increased plasma ACTH concentrations. Magnetic resonance imaging of the pituitary showed a microadenoma in seven patients, a macroadenoma in one patient and no adenoma in three patients. In these latter patients, pituitary ACTH overproduction was determined by sinus petrosus inferior sampling. Histological examination showed adenomatous tissue $(n=9$; case no. 1 and nos 4-11) or hyperplasia ( $n=2$; case nos 2 and 3$)$ with immunohistochemically expression of ACTH. All patients gave their informed consent for the use of tumour material for research purposes. After surgery, 7 of 11 patients were cured.

In six cases (nos 1-6) the tissue was directly snapfrozen on dry ice and stored at $-80^{\circ} \mathrm{C}$ until analysis. Adenoma tissue from the five additional patients (culture nos 7-11) was directly used for cell culturing.

\section{Quantitative PCR}

Quantitative PCR was performed as described previously (20). Briefly, poly $\mathrm{A}^{+}$mRNA was isolated from adenoma tissue using Dynabeads Oligo (dT)25 (Dynal AS, Oslo, Norway). cDNA was synthesized using the poly $\mathrm{A}^{+}$mRNA, which was eluted from the beads in $40 \mu \mathrm{H}_{2} \mathrm{O}$ for $2 \mathrm{~min}$ at $65^{\circ} \mathrm{C}$, using Oligo (dT) $12-18$ Primer (Invitrogen). One-twentieth of the cDNA library was used for quantification of sst subtype mRNA levels. A quantitative PCR was performed by TaqMan Gold nuclease assay (Perkin Elmer Corporation, Foster City, CA, USA) and the ABI PRISM 7700 sequence Detection System (Perkin Elmer, Groningen, The Netherlands) for real-time amplifications, according to manufacturer's protocol. The assay was performed using $15 \mu \mathrm{l}$ TaqMan Universal PCR Master Mix (Applied Biosystems, Alphen a/d Rÿn, The Netherlands), $500 \mathrm{nmol} / \mathrm{l}$ forward primer, $500 \mathrm{nmol} / \mathrm{l}$ reverse primer, $100 \mathrm{nmol} / \mathrm{l}$ probe and $10 \mu \mathrm{l} \mathrm{cDNA}$ template, in a total reaction volume of $25 \mu \mathrm{l}$. After an initial heating at $95^{\circ} \mathrm{C}$ for $8 \mathrm{~min}$, samples were subjected to 40 cycles of denaturation at $95^{\circ} \mathrm{C}$ for $15 \mathrm{~s}$ and annealing for $1 \mathrm{~min}$ at $60^{\circ} \mathrm{C}$. The primer and probe sequences that were used are indicated below. The detection of hypoxanthine-phosphoribosyl-transferase (HPRT) mRNA served as a control and was used for normalization of the sst subtype mRNA levels.

The primer and probe sequences that were used for the detection of $\mathrm{sst}_{1}, \mathrm{sst}_{2}, \mathrm{sst}_{3}, \mathrm{sst}_{5}$ and HPRT mRNAs have been described previously (20). In addition to these primers and probes, we also evaluated sst $_{4}$ mRNA expression in the present study using the following primers and probe: $\mathrm{sst}_{4}$ forward $5^{\prime}$-CTGCGCCAACCCTATTCTCT-3'; sst $_{4}$ reverse 5'-ACCCGCTGGAAGGATCG-3'; sst $_{4}$ probe 5'-FAM-TGGCTTCCTCTCCGACA- 
ACTTCCG-TAMRA- $3^{\prime}$. Primers and probes were purchased from Biosource (Nivelles, Belgium).

The relative amount of sst subtype mRNA was determined using a standard curve generated from known amounts of human genomic DNA. For determination of the amount of HPRT mRNA, a standard curve was generated of a pool of cDNAs from a human cell line known to express HPRT. The relative amount of sst subtype mRNA was calculated relative to the amount of HPRT mRNA and is given in arbitrary units. Each sample was assayed in duplicate. Poly $\mathrm{A}^{+}$ mRNA from AtT20/D16V cells was isolated as described above. PCR analysis to determine the expression of mouse $\mathrm{sst}_{1-5}$ mRNAs was performed as described elsewhere (21).

\section{Cell dispersion and cell culture}

Pituitary adenoma tissue Single cell suspensions of the pituitary adenoma tissues were prepared by enzymatic dissociation with dispase as described in detail previously (19). For short-term incubation of monolayer cultures, the dissociated cells were plated in 48well plates (Corning BV Life Sciences, Schiphol-Rijk, The Netherlands) at a density between 10000 and 50000 cells per well per $1 \mathrm{ml}$ culture medium. After 3-4 days the medium was changed and 4, 24 or $72 \mathrm{~h}$ incubations without or with test substances were initiated. At the end of the incubation the medium was collected and stored at $-20^{\circ} \mathrm{C}$ until hormone determination. The cells were cultured at $37^{\circ} \mathrm{C}$ in a $\mathrm{CO}_{2}$ incubator. The culture medium consisted of Minimum Essential Medium with Earle's salts supplemented with non-essential amino acids, sodium pyruvate $(1 \mathrm{mmol} / \mathrm{l}), \quad 10 \%$ fetal calf serum (FCS), penicillin $\left(1 \times 10^{5} \mathrm{U} / \mathrm{l}\right), \quad$ Fungizone $(0.5 \mathrm{mg} / \mathrm{l}), \quad$ L-glutamine $(2 \mathrm{mmol} / \mathrm{l})$, and sodium bicarbonate $(2.2 \mathrm{~g} / \mathrm{l}), \mathrm{pH}$ 7.6. Media and supplements were from Invitrogen. Unfortunately, not enough tumour material was obtained to test the adenoma cells at all time-points and the dosedependency of the effects by the indicated drugs.

Mouse corticotroph adenoma cells AtT20/D16V mouse corticotroph tumour cells (Dr J Tooze, European Organization for Molecular Biology) were routinely passaged by trypsinization as described in detail previously (22). The cells were maintained in $75 \mathrm{~cm}^{2}$ culture flasks in Dulbecco's Minimal Essential Medium, supplemented with non-essential amino acids, sodium pyruvate $(1 \mathrm{mmol} / \mathrm{l}), 10 \%$ FCS, penicillin $\left(1 \times 10^{5} \mathrm{U} / \mathrm{l}\right)$, Fungizone $(0.5 \mathrm{mg} / \mathrm{l})$, L-glutamine $(2 \mathrm{mmol} / \mathrm{l})$ and sodium bicarbonate $(2.2 \mathrm{~g} / \mathrm{l}), \mathrm{pH}$ 7.6. For experiments, the cells were seeded at a density of 20000 cells per well in $1 \mathrm{ml}$ of culture medium. After $72 \mathrm{~h}$, the medium was changed and 4,24 or $72 \mathrm{~h}$ incubations without or with OCT, SOM230 or SS-14 were initiated. In addition, the acute effect of SS-14, OCT and SOM230 was evaluated in a $3 \mathrm{~h}$ incubation without or with
$10 \mathrm{nmol} / \mathrm{l} \mathrm{CRH}$. In order to evaluate the effect of glucocorticoids on SS analogue-induced inhibition of ACTH release, the cells were pre-treated in some experiments for $48 \mathrm{~h}$ with the synthetic glucocorticoid DEX $(10 \mathrm{nmol} / \mathrm{l})$. Thereafter, the medium was changed and a $3 \mathrm{~h}$ incubation without or with OCT $(1 \mathrm{nmol} / \mathrm{l})$ or SOM230 $(1 \mathrm{nmol} / \mathrm{l})$ in the presence of CRH $(10 \mathrm{nmol} / \mathrm{l})$ was performed. After the indicated time periods, the medium was collected and stored at $-20^{\circ} \mathrm{C}$ until determination of ACTH concentrations. For determining the effects of the compounds on cell growth, $\left[{ }^{3} \mathrm{H}\right]$ thymidine incorporation, as well as the DNA content of the wells, was measured as described in detail elsewhere (23).

\section{Hormone determinations}

Human ACTH concentrations were determined by a non-isotopic, automatic chemiluminescence immunoassay system (Immulite; DPC Inc., Los Angeles, CA, USA). Intra- and interassay coefficient of variation (CV) values were 5.6 and $7.8 \%$ respectively. Human growth hormone $(\mathrm{GH})$, prolactin (PRL), luteinizing hormone (LH) and follicle-stimulating hormone (FSH) concentrations in the media were determined, in order to exclude the presence of contaminating normal pituitary cells in the cultures. GH, PRL, LH and FSH concentrations were determined by a non-isotopic, automatic chemiluminescence immunoassay system as well (Immulite; DPC). Intra- and interassay CV values for GH, PRL, LH and FSH were 6.0, 5.7, 5.7 and $6.4 \%$ and $6.2,6.4,12.3$ and $7.5 \%$ respectively. Except for the expected hormone ACTH, none of the other hormones was detected (not shown).

\section{Test substances}

OCT (Sandostatin) was obtained from Novartis Pharma AG (Basle, Switzerland). SOM230 was a gift from Novartis Pharma AG. SS-14 was purchased from Sigma Chemical Co. Binding affinities of SS-14, OCT and SOM230 to the five sst subtypes are shown in Table 1. DEX was obtained from the Erasmus MC Pharmacy (Rotterdam, The Netherlands). CRH was purchased from Ferring (Hoofddorp, The Netherlands).

\section{Statistical analysis of the data}

All data on hormone release are expressed as means \pm S.E., $n=4$ wells per treatment group. All data were analysed by ANOVA to determine overall differences between treatment groups. When significant differences were found by ANOVA, a multiple comparison between treatment groups was made using the Newman-Keuls test. Calculation of $\mathrm{IC}_{50}$ values for inhibition of hormone release were made using GraphPad Prism (San Diego, CA, USA). 
Table 1 Binding affinity of SS-14, OCT and SOM230 for the five human sst subtypes, sst $_{1-5}$. Data are reproduced with permission from the society of the European Journal of Endocrinology (17). Results are mean \pm S.E. $I_{50}$ values (nmol/l).

\begin{tabular}{lccccc}
\hline Compound & hsst $_{\mathbf{1}}$ & hsst $_{\mathbf{2}}$ & hsst $_{\mathbf{3}}$ & hsst $_{\mathbf{4}}$ & hsst $_{\mathbf{5}}$ \\
\hline SS-14 & $0.93 \pm 0.12$ & $0.15 \pm 0.02$ & $0.56 \pm 0.17$ & $1.5 \pm 0.4$ & $0.29 \pm 0.04$ \\
OCT & $280 \pm 80$ & $0.38 \pm 0.08$ & $7.1 \pm 1.4$ & $>1000$ & $6.3 \pm 1.0$ \\
SOM230 & $9.3 \pm 0.1$ & $1.0 \pm 0.1$ & $1.5 \pm 0.3$ & $>100$ & $0.16 \pm 0.01$ \\
\hline
\end{tabular}

\section{Results}

\section{sst subtype mRNA expression}

In six out six human corticotroph adenomas (nos 1-6), $\mathrm{sst}_{2}$ mRNA was detectable. However, the relative copy numbers were low (varying between 8 and 141 copies/HPRT). The relative $s t_{2}$ copy number was considerably lower compared with the majority of $\mathrm{GH}-$ secreting pituitary adenomas, as recently reported (20). sst $_{5}$ mRNA was detectable at much higher levels in six out of six adenomas (relative copy number between 277 and 1217). In the two cases in which histological analysis of the tissue revealed hyperplasia of ACTH-producing cells (case nos 2 and 3), sst ${ }_{5}$ mRNA levels were relatively high. On the other hand, one ACTH-secreting pituitary adenoma (case no. 1) expressed the highest level of sst $_{5}$ mRNA in the series. $\mathrm{sst}_{1}, \mathrm{sst}_{3}$ and $\mathrm{sst}_{4}$ mRNA was detectable at low levels in only one, two and two out of six samples respectively (Fig. 1).

In agreement with the results of RT-PCR analysis of the corticotroph adenomas, the sst subtype mRNAs expressed in ACTH-secreting mouse AtT20 corticotroph pituitary tumour cells were $\mathrm{sst}_{2}, \mathrm{sst}_{3}$ (low abundance) and sst ${ }_{5}$ (Fig. 2).

\section{Effect of SS-14, OCT and SOM230 on basal and CRH-induced ACTH secretion by primary corticotroph adenoma cells}

Since not sufficient tissue was obtained to carry out both mRNA and culture studies on the same tissue, cell culture experiments were performed using adenoma tissue from five additional patients (nos 7-11). In a $72 \mathrm{~h}$ incubation, SOM $230(10 \mathrm{nmol} / \mathrm{l})$ significantly suppressed ACTH secretion in three out of five primary cultures of human corticotroph adenomas (between 30 and $40 \%$ suppression). In contrast, OCT $(10 \mathrm{nmol} / \mathrm{l})$ suppressed basal ACTH release in only one out of five cultures (28\% suppression) (Fig. 3A and B). From one corticotroph adenoma (no. 8) sufficient cells were obtained to perform a time-course study of the effects of SS-14, OCT and SOM230 on basal ACTH release. As shown in Fig. 4A (4, 24 and $72 \mathrm{~h}$ incubation), statistically significant $(P<0.01$ vs untreated control cells) suppression of ACTH release was observed only after $72 \mathrm{~h}$ of incubation with SOM230 $(10 \mathrm{nmol} / \mathrm{l})$ and SS-14 $(10 \mathrm{nmol} / \mathrm{l})$. Ten $\mathrm{nmol} / \mathrm{l}$ of OCT did not significantly inhibit basal ACTH release at any timepoint. A comparable time-course experiment was performed in mouse AtT20 cells. In agreement with the observations in primary human corticotroph adenoma cultures, SOM230 and SS-14, but not OCT, all tested at $10 \mathrm{nmol} / \mathrm{l}$, suppressed basal ACTH production (Fig. 4B). The effect of SOM230 on basal ACTH release by AtT20 cells was dose-dependent with an $\mathrm{IC}_{50}$ value of $0.2 \mathrm{nmol} / \mathrm{l}$ (Fig. 5A), corresponding to the binding affinity of SOM230 for sst ${ }_{5}$. In contrast, OCT inhibited ACTH release with much lower potency with a slight suppression at $100 \mathrm{nmol} / \mathrm{l}$ (Fig. 5A). Taken together, these data suggest that the effect of SOM230 on basal ACTH release is most probably mediated via sst ${ }_{5}$. OCT and SOM230 did not inhibit AtT20 cell proliferation as measured by $\left[{ }^{3} \mathrm{H}\right]$ thymidine incorporation (Fig. $5 \mathrm{~B}$ ), and had no effect on the DNA content of the cells (not shown).

In contrast to the absence of an effect of OCT on basal ACTH release by AtT20 cells, OCT $(10 \mathrm{nmol} / \mathrm{l})$ significantly suppressed CRH $(10 \mathrm{nmol} / \mathrm{l})$-induced ACTH release by $52 \%$ and SS- 14 by $47 \%$ in a $3 \mathrm{~h}$ incubation. SOM230 was significantly more potent and inhibited CRH-induced ACTH release by $76 \%$ (Fig. 6). The effect of SS-14 on CRH-induced ACTH-release by AtT20 cells is in agreement with previous reports (24-26).

\section{Effect of glucocorticoid pre-treatment}

In order to evaluate whether pre-treatment of the cells with glucocorticoids influenced the sensitivity to the effects of OCT and SOM230, mouse AtT20 cells were pre-treated with $10 \mathrm{nmol} / \mathrm{l}$ DEX during $48 \mathrm{~h}$, after which a $3 \mathrm{~h}$ incubation without or with $\mathrm{CRH}$ $(10 \mathrm{nmol} / \mathrm{l})$, OCT $(1 \mathrm{nmol} / \mathrm{l})$ and/or SOM230 $(1 \mathrm{nmol} / \mathrm{l})$ was performed. Figure 7 shows that pretreatment of AtT20 cells with $10 \mathrm{nmol} / \mathrm{l}$ DEX had no effect on the inhibitory effect of SOM230 on CRHinduced ACTH release. On the other hand, the inhibitory effect of $1 \mathrm{nmol} / \mathrm{l}$ OCT was completely abolished by DEX pre-treatment. In the presence of DEX, SOM230 almost completely abolished CRH-induced ACTH release (Fig. 7, lower panel). Finally, DEX pretreatment did not change the inhibitory effects of $10 \mathrm{nmol} / \mathrm{l} \mathrm{OCT}$ or SOM230 on CRH-induced ACTH release (data not shown), suggesting that OCT at $10 \mathrm{nmol} / \mathrm{l}$ induced its inhibitory effect via interaction with $s t_{5}$, for which it has significantly lower affinity 

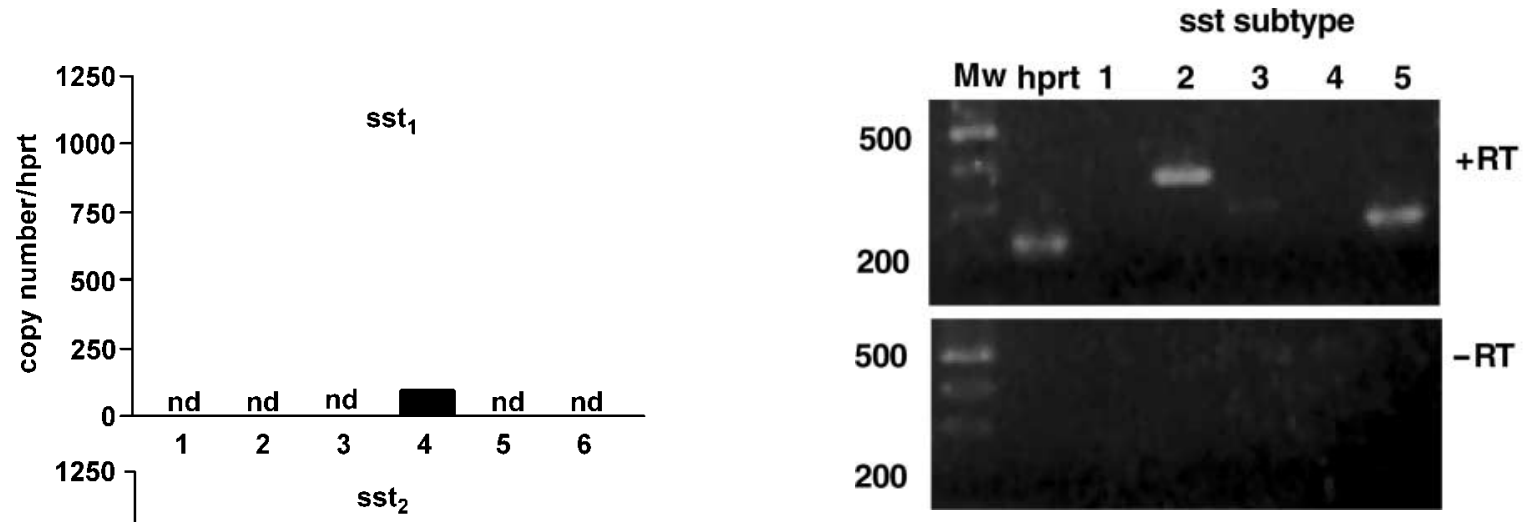

Figure 2 Expression of sst subtypes in mouse AtT20 pituitary tumour cells. Poly $\mathrm{A}^{+} \mathrm{mRNA}$ was reverse transcribed and $\mathrm{cDNA}$ was amplified by PCR. PCR products of the sst $_{1-5}$ were separated on $1 \%$ agarose gel and stained with ethidium bromide. Upper panel represents cDNA synthesis in the presence of reverse transcriptase $(+R T)$; lower panel represents negative control of cDNA synthesis in the absence of RT (-RT) to exclude the presence of genomic DNA contamination. Only bands of $s_{2}$, sst $_{3}$ and sst $_{5}$ PCR products with the expected molecular weight (Mw) were detected.

compared with SOM230 (Table 1). Moreover, in one primary culture of corticotroph adenoma cells (case no. 4), which was unresponsive to OCT, DEX $(10 \mathrm{nmol} / \mathrm{l})$ pre-treatment did not reduce the inhibitory effect by SOM230 on CRH (10 nmol/l)-induced ACTH release as well $(-21 \%$ without DEX vs $-33 \%$ in the presence of DEX).

\section{Discussion}

Currently, there is no effective medical treatment option in patients with pituitary-dependent Cushing's disease $(3,4)$. Therefore, in the present study we evaluated the effects of the recently developed multi-ligand stable SS analogue SOM230 $(17,18,27)$, which has high binding affinity to $\mathrm{sst}_{1}, \mathrm{sst}_{2}, \mathrm{sst}_{3}$ and $\mathrm{sst}_{5}$, on ACTH release by human corticotroph tumours in vitro.

The role of SS in the regulation of normal ACTH release is equivocal. Previous in vitro studies showed no inhibitory effect of SS on basal and CRH-induced ACTH release by normal rat anterior pituitary cells (28) and perifused normal rat pituitary halves (29). On the other hand, SS inhibited CRH-stimulated ACTH release by fragments of pituitary glands (30), as well as arginine vasopressin-induced ACTH release by cultured pituitary cells from long-term adrenalectomized rats (31). The latter study suggests that normal corticotrophs only respond to SS in the presence of very low cortisol concentrations. Confirming this hypothesis, we demonstrated that SS inhibits CRH-stimulated ACTH secretion by normal rat anterior pituitary cells only when the cells are cultured in the absence of glucocorticoids in the culture medium (32). In addition, pre-incubation of the cells with the 
(A)

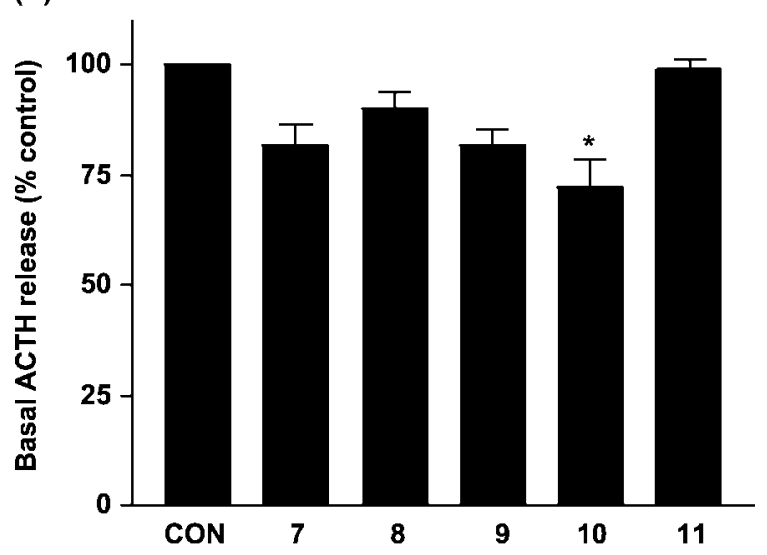

(B)

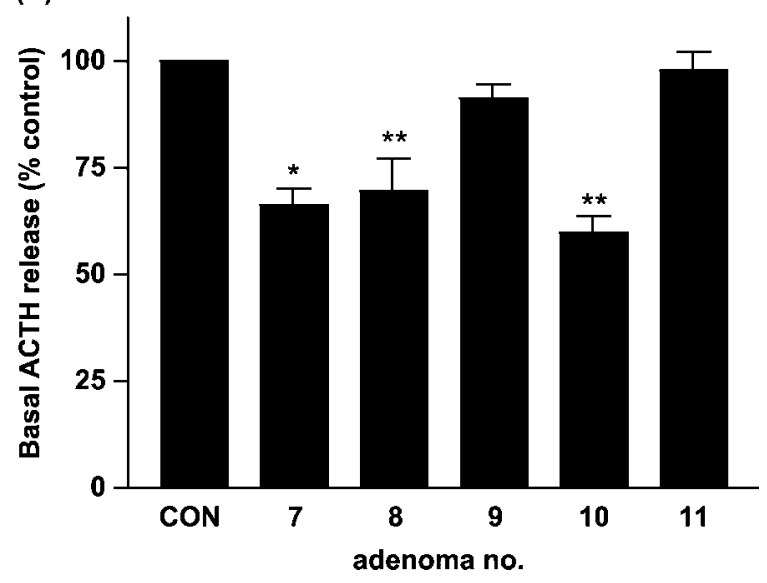

Figure 3 Effect of $10 \mathrm{nmol} / /$ OCT (A) and $10 \mathrm{nmol} / \mathrm{I} \mathrm{SOM} 230$ (B) on basal ACTH release from five cultured human corticotroph adenomas (nos 7-11). The cells were incubated in the absence or presence of OCT (A) or SOM230 (B) during $72 \mathrm{~h}$ after which the medium was collected for ACTH determination. Values are expressed as per cent of control (CON; untreated cells). Basal ACTH concentrations in the culture media were $239 \pm 5.0$, $28800 \pm 1159,25100 \pm 2150,218 \pm 12$ and $3228 \pm 153 \mathrm{fmol} / \mathrm{well}$, for cultured adenomas nos 7, 8, 9, 10 and 11 respectively. ${ }^{\star} P<0.05$ and ${ }^{* *} P<0.01$ vs control. Means \pm S.E., $n=4$ wells per treatment group.

progesterone-glucocorticoid receptor-blocking compound RU 38486 , increased the sensitivity of ACTH secretion to the inhibitory effect by SS and pre-treatment with DEX made the cells insensitive to SS (32). The high levels of cortisol in patients with pituitarydependent Cushing's disease can thus be responsible for the observed lack of inhibition of ACTH release by SS and/or OCT in these patients $(6,11,33)$. Moreover, in patients with Nelson syndrome and adrenal insufficiency of different origins, SS and/or OCT lower ACTH secretion $(6,9,34,35)$. In cultured corticotroph adenomas, SS and/or OCT inhibit ACTH secretion in part of the cultures $(11,36-38)$. Stalla et al. (11) showed that hydrocortisone treatment in vitro abolished the inhibitory effect of OCT on ACTH secretion, possibly due to a downregulation of sst on the corticotrophs.
In agreement with this hypothesis, cortisol reduced $\left[{ }^{125} \mathrm{I}^{-T_{y r}}{ }^{1}\right]$ SS binding on mouse AtT20/D16 pituitary tumour cells by $20-40 \%$ (39), although the sst subtype was not characterized.

Little is known with respect to sst subtype expression in pituitary corticotrophs. In rat pituitary cells, co-localization of all five sst subtypes with ACTH-expressing cells has been reported (40). In another study, sst ${ }_{5}$ mRNA was found in $38 \%$ of normal corticotrophs, and sst 2 in only $3 \%$. Moreover, the average number of grains per cell was also higher for sst $_{5}$ than $\mathrm{sst}_{2}$ (12). This suggests that under normal physiological conditions, sst $_{5}$ is predominantly more expressed in rat corticotrophs than sst $_{2}$. As far as is known, no data on the quantitative expression of sst mRNA in human corticotroph adenomas are available. In the present study we found that at the mRNA level, sst $_{5}$ was the predominantly expressed receptor type in human corticotroph adenomas. In the small series of tissues $(n=6)$ analysed in this study, two cases of hyperplasia of corticotroph cells expressed a relatively high sst ${ }_{5} \mathrm{mRNA}$ level. On the other hand, one corticotroph adenoma expressed the highest sst $_{5}$ mRNA level in this series. The number of cases is too low, however, to establish whether there is a difference in sst $_{5}$ mRNA expression between hyperplasia of ACTH-producing cells and ACTH-secreting adenoma. sst $_{2}$ mRNA was expressed in all cases as well, although at a much lower level. The high frequency of expression of sst ${ }_{2}$ and sst $_{5}$ in corticotroph adenomas is well in agreement with other reports. mRNA expression in human corticotroph tumours shows the overall presence of sst $_{1}$ in five out of eight (63\%), sst ${ }_{2}$ in seven out of eight $(88 \%)$, sst $_{3}$ in three out of nine $(33 \%)$, sst $_{4}$ in one out of eight $(12 \%)$, and sst ${ }_{5}$ in six out of seven $(86 \%)$ cases $(13-15,41,42)$. The low expression levels of $\mathrm{sst}_{2}$ may explain the lack of efficacy of the $s t_{2}$-preferring agonist OCT in lowering circulating ACTH and cortisol levels in untreated patients with pituitary-dependent Cushing's disease $(6,11)$. In vitro we found a statistically significant inhibition of basal ACTH release by OCT in only one out of five cases. The higher number of cultures (three out of five) responding to a maximally active concentration of $10 \mathrm{nmol} / \mathrm{l} \mathrm{SOM} 230$, which has very high binding affinity for $\mathrm{sst}_{5}$, is in agreement with the higher expression levels of sst $_{5}$ mRNA. Unfortunately, not enough tissue was obtained to perform both mRNA analysis and cell culture studies. In one adenoma, which had an intermediate sst ${ }_{5}$ mRNA level (case no. 4), SOM230 already inhibited ACTH secretion, whereas OCT had no effect. It should be noted that only mRNA levels were studied. Future studies should demonstrate whether sst ${ }_{5}$ receptors are expressed in corticotroph adenomas at a high protein level as well. The importance of sst ${ }_{5}$ in regulating ACTH release was further confirmed by our observation that SOM230 was also much more potent compared with OCT in inhibiting basal ACTH release by mouse AtT20/D16V corticotroph tumour cells. The pattern of inhibition, e.g. a higher potency of SOM230 vs OCT, is 

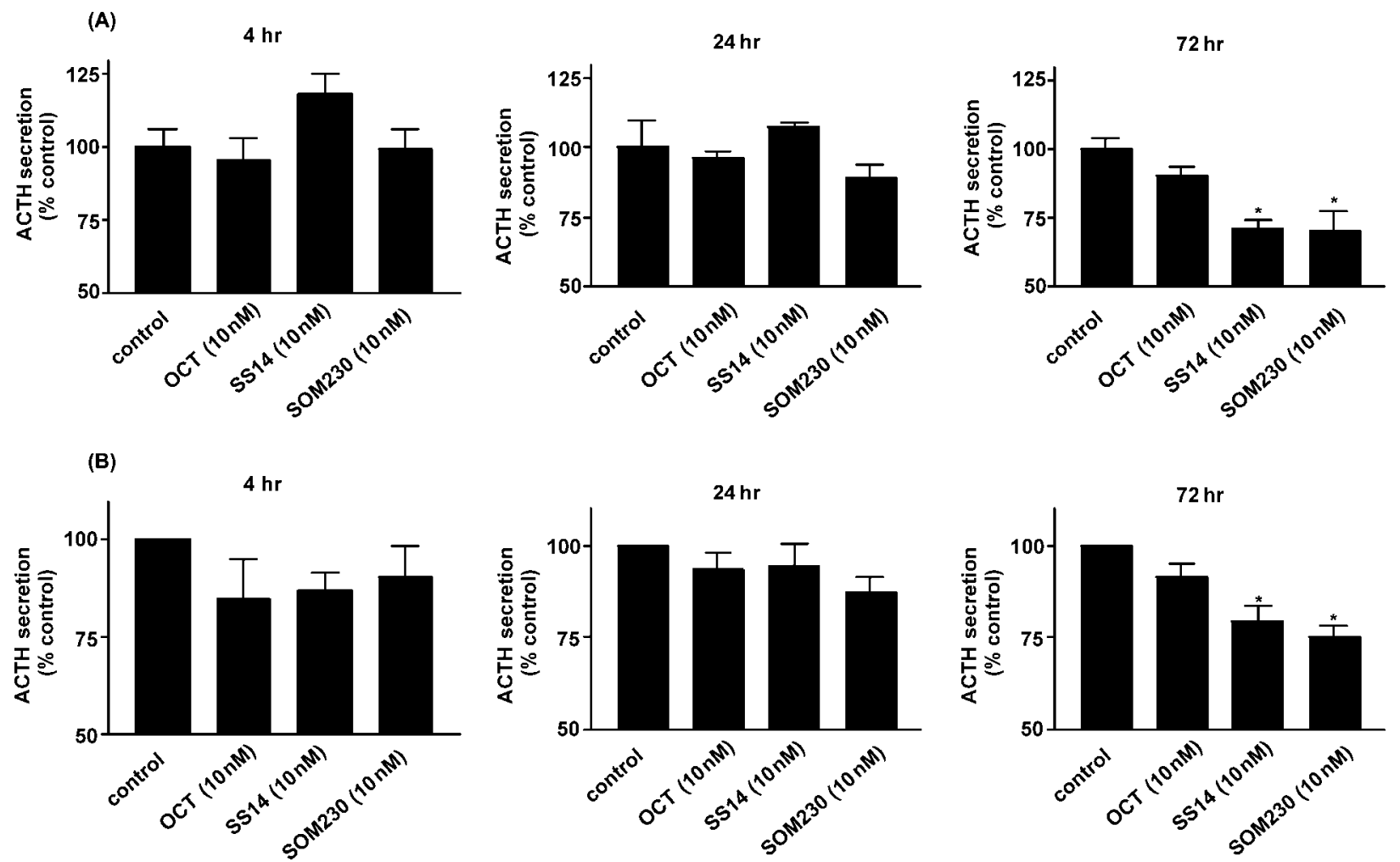

Figure 4 Time-dependent effect of OCT $(10 \mathrm{nmol} / \mathrm{l})$, SOM230 $(10 \mathrm{nmol} / \mathrm{l})$ and SS-14 $(10 \mathrm{nmol} / \mathrm{l})$ on basal ACTH release from cultured human corticotroph adenoma no. 8 (A) and mouse AtT20 corticotroph tumour (B) cells. The cells were incubated for 4,24 or $72 \mathrm{~h}$ in the absence or presence of the indicated compounds, after which medium was collected for ACTH determination. Values are expressed as the per cent of ACTH release by control (untreated) cells at the indicated time-points. For the human corticotroph adenoma cells, basal ACTH values were $3505 \pm 232(4 \mathrm{~h}), 9778 \pm 946(24 \mathrm{~h})$ and $28800 \pm 1159(72 \mathrm{~h}) \mathrm{fmol} /$ well. ${ }^{*} P<0.01$ vs control. Means \pm S.E., $n=4 \mathrm{wells}$ per treatment group.

in line with the sst binding profile of both SS analogues. Recently, Cervia et al. (43) showed that sst $_{2}$ is the predominant functional receptor subtype in AtT20 cells, while sst $_{5}$ is also able to mediate inhibition of ACTH release when the ligand is not able to activate sst $_{2}$ receptors. Interestingly, while SOM230 was much more potent in inhibiting basal ACTH release by AtT20 cells, we found that OCT also potently inhibited $\mathrm{CRH}$-induced ACTH release. However, maximal inhibition of ACTH by SOM230 was significantly higher compared with OCT. These data suggest that expression of $\mathrm{sst}_{2}$ in our AtT20 line is relatively low, compared with sst $_{5}$. The involvement of both $\mathrm{sst}_{2}$ and $\mathrm{sst}_{5}$ in the regulation of ACTH release is further underlined by the observation that sst $_{2-}$ and sst $_{5}$-specific agonists potently inhibit ACTH release and cAMP production by AtT20 cells (44).

As indicated above, glucocorticoids may downregulate sst on AtT20 corticotrophs and lower responsiveness of ACTH to the inhibitory effect of SS and/or OCT. Therefore, we also studied whether pre-treatment of the cells with the synthetic glucocorticoid DEX $(10 \mathrm{nmol} / \mathrm{l})$ reduced responsiveness of the cells to inhibition of ACTH release by SOM230. We found that glucocorticoid pre-treatment did not influence the inhibitory effect of SOM230 on CRH-induced ACTH release, suggesting that the expression of functional sst $_{5}$ receptors is relatively resistant to glucocorticoids. This may also explain the higher expression levels of sst $_{5}$ mRNA we found in human corticotroph adenomas from untreated patients with pituitary-dependent Cushing's disease. These data suggest that glucocorticoids may have differential regulatory effects on $\mathrm{sst}_{2}$ and sst $_{5}$ expression. An intriguing observation is that SOM230 and SS-14 only inhibit basal ACTH secretion after prolonged in vitro exposure. SOM230 did not inhibit AtT20 cell proliferation. Therefore, other mechanisms, e.g. inhibition of pro-opiomelanocortin synthesis and/or increased ACTH breakdown, as has been shown for the effect of OCT on GH-secreting pituitary adenomas $(45,46)$, may form additional explanations for the inhibitory effect of SOM230 and SS-14 on basal ACTH secretion. Interestingly, recent evidence suggests that sst $_{5}$ is also important in the control of ACTH secretion in vivo. sst $_{5}$ knock-out mice were shown to have significantly elevated ACTH and corticosterone levels, compared with wild-type mice (47).

While our data suggest that the novel SS analogue SOM230 may be useful in the medical management of 
(A)

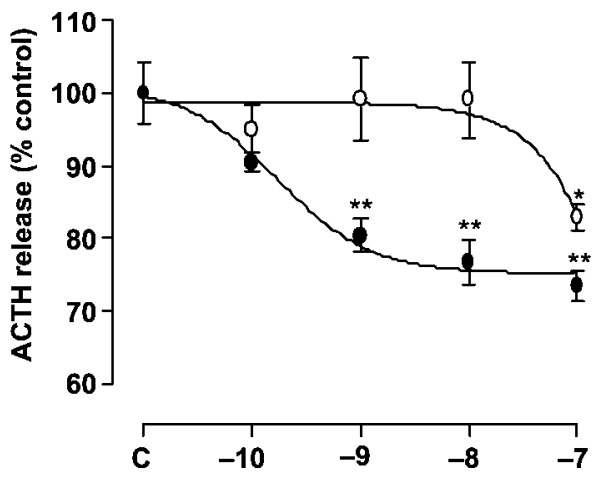

(B)

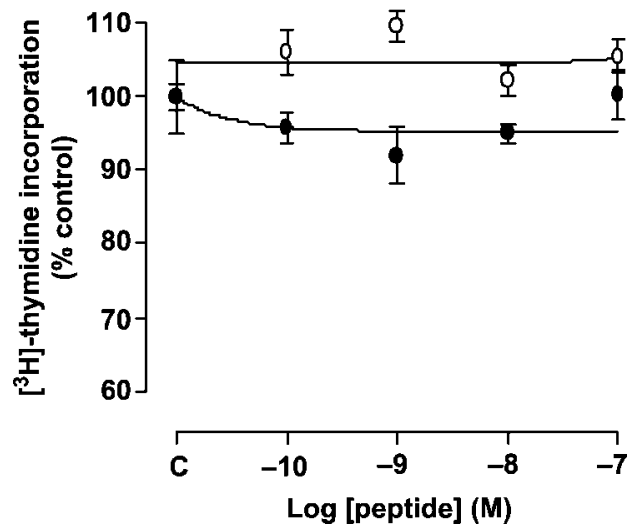

Figure 5 Dose-dependent effect of SOM230 and OCT on basal ACTH release $(A)$ and cell proliferation as measured by $\left[{ }^{3} \mathrm{H}\right]$ thymidine incorporation (B) by mouse AtT20 pituitary tumour cells. AtT20 cells were incubated during $72 \mathrm{~h}$ without or with increasing concentrations of OCT $(\mathrm{O})$ or SOM230 $(\bullet)$, after which the medium was collected for ACTH determination. Values are expressed as the per cent of control (untreated) cells. ${ }^{*} P<0.05$ and ${ }^{* \star} P<0.01$ vs control. Means \pm S.E., $n=4$ wells per treatment group.

patients with pituitary-dependent Cushing's disease, several issues will have to be clarified. First, prolonged treatment of AtT20 cells with SS-14 results in desensitization of its inhibitory effect on ACTH secretion and cAMP formation $(48,49)$. In addition, prolonged agonist exposure of AtT20 cells with SS-14 or SS-28 was shown to downregulate SS-14 receptors (50). However, these studies only evaluated the acute inhibitory effects of SS-14 on AtT20 cells. Moreover, the effects of SOM230 are most likely sst $_{5}$-mediated and sst $_{5}$ receptors have shown to be rapidly recycled and recruited from intracellular storages after agonist activation. This combination of recycling and recruitment of spare sst $_{5}$ receptors may protect from long-term downregulation through sequestration and, therefore, facilitate extended SS signalling (51). We observed that the inhibitory effects of SOM230 on basal ACTH secretion became only apparent after prolonged exposure. This observation already suggests that endogenously expressed sst $_{5}$ receptors may be more resistant to desensitization and/or downregulation. Nevertheless, the in vivo effect
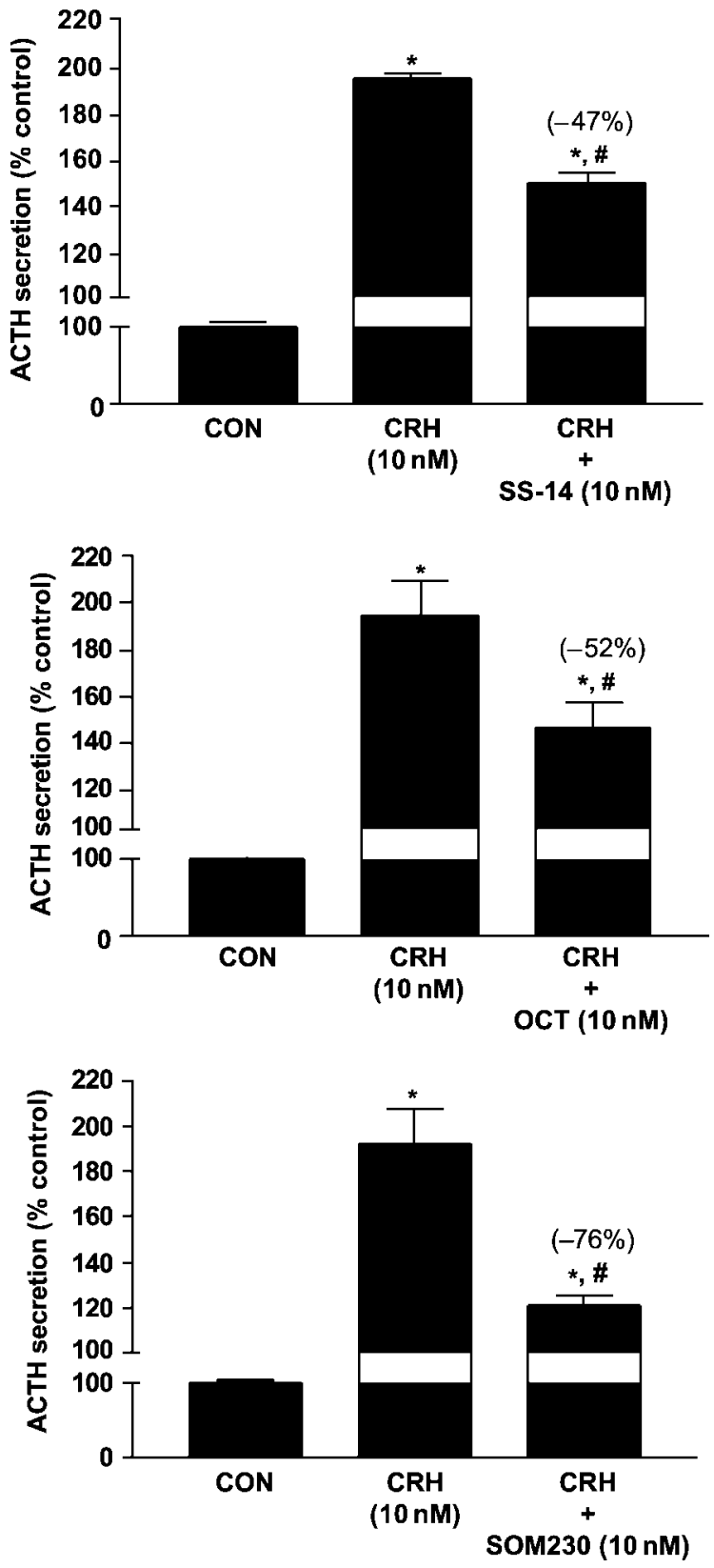

Figure 6 Effect of OCT, SS-14 and SOM230 on CRH-stimulated ACTH release by mouse AtT20 pituitary tumour cells. AtT20 cells were incubated for $3 \mathrm{~h}$ in the absence or presence of $\mathrm{CRH}$ together with either SS-14, OCT or SOM230, after which the medium was collected for ACTH determination. Values are expressed as the per cent of control (untreated) cells. ${ }^{\star} P<0.01$ vs control, ${ }^{\#} P<0.01$ vs $\mathrm{CRH}$ alone. Means \pm S.E., $n=4$ wells per treatment group.

of SOM230 on ACTH secretion by corticotroph adenomas needs to be further evaluated.

In conclusion, the selective expression of sst $_{5}$ receptors in human corticotroph adenomas, in combination with the inhibitory effect of SOM230 on basal and CRH-induced ACTH secretion, suggests that SOM230 may have potential in the medical treatment of pituitary-dependent Cushing's disease. 

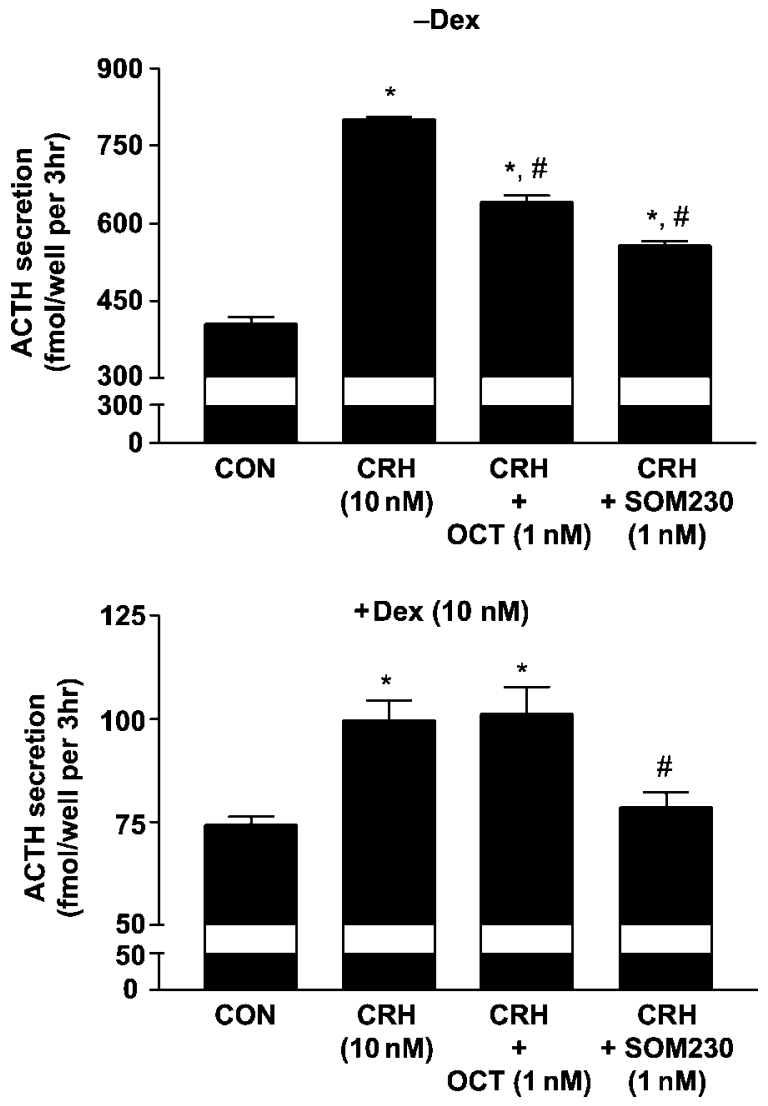

Figure 7 Effect of glucocorticoids on OCT- and SOM230mediated inhibition of $\mathrm{CRH}$-stimulated $\mathrm{ACTH}$ release by mouse AtT20 pituitary adenoma cells. AtT20 cells were pre-incubated during $48 \mathrm{~h}$ without or with $10 \mathrm{nmol} / \mathrm{I} \mathrm{DEX}$. After $48 \mathrm{~h}$, the medium was refreshed and the cells were incubated for $3 \mathrm{~h}$ in the absence or presence of DEX, CRH $(10 \mathrm{nmol} / \mathrm{l})$ and OCT $(1 \mathrm{nmol} / \mathrm{l})$ or SOM230 $(1 \mathrm{nmol} / \mathrm{l})$, after which the medium was collected for ACTH determination. ${ }^{*} P<0.01$ vs control, ${ }^{\#} P<0.01$ vs $\mathrm{CRH}$ alone. Means \pm S.E., $n=4$ wells per treatment group.

\section{References}

1 Orrego JJ \& Barkan AL. Pituitary disorders. Drug treatment options. Drugs 200059 93-106.

2 Colao A, Di Sarno A, Marzullo P, Di Somma C, Cerbone G, Landi ML, Faggiano A, Merola B \& Lombardi G. New medical approaches in pituitary adenomas. Hormone Research 200053 76-87.

3 Morris D \& Grossman A. The medical management of Cushing's syndrome. Annals of the New York Academy of Sciences 2002 $970119-133$.

4 Miller JW \& Crapo L. The medical treatment of Cushing's syndrome. Endocrine Reviews 199314 443-458.

5 De Herder WW, Kwekkeboom DJ, Reys AEM, Kooy PPM, Hofland L, Krenning E \& Lamberts SW. Receptor scintigraphy with somatostatin analogues and dopamine antagonists of pituitary tumours. In Pituitary Adenomas. From Basic Research to Diagnosis and Therapy, pp 93-104. Eds K von Werder \& R Fahlbush. Amsterdam: Elsevier Science BV, 1996.

6 Lamberts SW, Uitterlinden P \& Klijn JM. The effect of the longacting somatostatin analogue SMS 201-995 on ACTH secretion in Nelson's syndrome and Cushing's disease. Acta Endocrinologica $1989120760-766$.

7 De Herder WW \& Lamberts SW. Octapeptide somatostatin-analogue therapy of Cushing's syndrome. Postgraduate Medical Journal $19997565-66$
8 Lamberts SW, De Herder WW, Krenning EP \& Reubi JC. A role of (labeled) somatostatin analogs in the differential diagnosis and treatment of Cushing's syndrome. Journal of Clinical Endocrinology and Metabolism $1994 \mathbf{7 8}$ 17-19.

9 Tyrrell JB, Lorenzi M, Gerich JE \& Forsham PH. Inhibition by somatostatin of ACTH secretion in Nelson's syndrome. Journal of Clinical Endocrinology and Metabolism $1975 \mathbf{4 0}$ 1125-1127.

10 Newell-Price J, Trainer P, Besser M \& Grossman A. The diagnosis and differential diagnosis of Cushing's syndrome and pseudoCushing's states. Endocrine Reviews 199819 647-672.

11 Stalla GK, Brockmeier SJ, Renner U, Newton C, Buchfelder M, Stalla J \& Muller OA. Octreotide exerts different effects in vivo and in vitro in Cushing's disease. European Journal of Endocrinology $1994130125-131$.

12 Day R, Dong W, Panetta R, Kraicer J, Greenwood MT \& Patel YC. Expression of mRNA for somatostatin receptor (sstr) types 2 and 5 in individual rat pituitary cells. A double labeling in situ hybridization analysis. Endocrinology $19951365232-5235$.

13 Miller GM, Alexander JM, Bikkal HA, Katznelson L, Zervas NT \& Klibanski A. Somatostatin receptor subtype gene expression in pituitary adenomas. Journal of Clinical Endocrinology and Metabolism $1995801386-1392$.

14 Panetta R \& Patel YC. Expression of mRNA for all five human somatostatin receptors (hSSTR1-5) in pituitary tumors. Life Sciences $1995 \mathbf{5 6} 333-342$.

15 Greenman Y \& Melmed S. Expression of three somatostatin receptor subtypes in pituitary adenomas: evidence for preferential SSTR 5 expression in the mammosomatotroph lineage. Journal of Clinical Endocrinology and Metabolism 199479 $724-729$.

16 Nielsen S, Mellemkjaer S, Rasmussen LM, Ledet T, Astrup J, Weeke J \& Jorgensen JO. Gene transcription of receptors for growth hormone-releasing peptide and somatostatin in human pituitary adenomas. Journal of Clinical Endocrinology and Metabolism $1998832997-3000$.

17 Bruns C, Lewis I, Briner U, Meno-Tetang G \& Weckbecker G. SOM230: a novel somatostatin peptidomimetic with broad somatotropin release inhibiting factor (SRIF) receptor binding and a unique antisecretory profile. European Journal of Endocrinology 2002146 707-716.

18 Weckbecker G, Briner U, Lewis I \& Bruns C. SOM230: a new somatostatin peptidomimetic with potent inhibitory effects on the growth hormone/insulin-like growth factor-I axis in rats, primates, and dogs. Endocrinology 2002143 4123-4130.

19 Oosterom R, Blaauw G, Singh R, Verleun T \& Lamberts SW. Isolation of large numbers of dispersed human pituitary adenoma cells obtained by aspiration. Journal of Endocrinological Investigation $19847307-311$.

20 Hofland LJ, Van Der Hoek J, Van Koetsveld PM, De Herder WW, Waaijers M, Sprij-Mooij D, Bruns C, Weckbecker G, Feelders R, Van Der Lely AJ, Beckers A \& Lamberts SW. The novel somatostatin analog SOM230 is a potent inhibitor of hormone release by growth hormone- and prolactin-secreting pituitary adenomas in vitro. Journal of Clinical Endocrinology and Metabolism 200489 $1577-1585$.

21 Hofland LJ, Lamberts SW, Van Hagen PM, Reubi JC, Schaeffer J, Waaijers M, Van Koetsveld PM, Srinivasan A, Krenning EP \& Breeman WA. Crucial role for somatostatin receptor subtype 2 in determining the uptake of $\left[{ }^{111}\right.$ In-DTPA-D-Phe1]octreotide in somatostatin receptor-positive organs. Journal of Nuclear Medicine 200344 1315-1321.

22 Hofland LJ, Van Koetsveld PM, Waaijers M, Zuyderwijk J, Breeman WA \& Lamberts SW. Internalization of the radioiodinated somatostatin analog [ $\left.{ }^{125} \mathrm{I}-\mathrm{Tyr} 3\right]$ octreotide by mouse and human pituitary tumor cells: increase by unlabeled octreotide. Endocrinology $19951363698-3706$.

23 Ferone D, Van Hagen PM, Van Koetsveld PM, Zuijderwijk J, Mooy DM, Lichtenauer-Kaligis EG, Colao A, Bogers AJ, Lombardi G, Lamberts SW \& Hofland LJ. In vitro characterization of somatostatin receptors in the human thymus and effects of 
somatostatin and octreotide on cultured thymic epithelial cells Endocrinology 1999140 373-380.

24 Richardson UI \& Schonbrunn A. Inhibition of adrenocorticotropin secretion by somatostatin in pituitary cells in culture. Endocrinology $1981108281-290$.

25 Richardson UI. ACTH secretion in mouse pituitary tumor cells in culture: inhibition of CRF-stimulated hormone release by somatostatin. Life Sciences 198333 1981-1988.

26 Litvin Y, Leiser M, Fleischer N \& Erlichman J. Somatostatin inhibits corticotropin-releasing factor-stimulated adrenocorticotropin release, adenylate cyclase, and activation of adenosine $3^{\prime}, 5^{\prime}-$ monophosphate-dependent protein kinase isoenzymes in AtT20 cells. Endocrinology $1986119737-745$.

27 Lewis I, Bauer W, Albert R, Chandramouli N, Pless J, Weckbecker G \& Bruns C. A novel somatostatin mimic with broad somatotropin release inhibitory factor receptor binding and superior therapeutic potential. Journal of Medicinal Chemistry $2003462334-2344$.

28 Brown MR, Rivier C \& Vale W. Central nervous system regulation of adrenocorticotropin secretion: role of somatostatins. Endocrinology 1984114 1546-1549.

29 Kraicer J, Gajewski TC \& Moor BC. Release of pro-opiomelanocortin-derived peptides from the pars intermedia and pars distalis of the rat pituitary: effect of corticotrophin-releasing factor and somatostatin. Neuroendocrinology 198541 363-373.

30 Nicholson SA, Adrian TE, Gillham B, Jones MT \& Bloom SR. Effect of hypothalamic neuropeptides on corticotrophin release from quarters of rat anterior pituitary gland in vitro. Journal of Endocrinology $1984100219-226$.

31 Voight KH, Fehm HL, Lang RE \& Walter R. The effect of somatostatin and of prolyl-leucyl-glycinamide (MIF) on ACTH release in dispersed pituitary cells. Life Sciences 197721 739-745.

32 Lamberts SW, Zuyderwijk J, Den Holder F, Van Koetsveld P \& Hofland L. Studies on the conditions determining the inhibitory effect of somatostatin on adrenocorticotropin, prolactin and thyrotropin release by cultured rat pituitary cells. Neuroendocrinology $19895044-50$.

33 Ambrosi B, Bochicchio D, Fadin C, Colombo P \& Faglia G. Failure of somatostatin and octreotide to acutely affect the hypothalamicpituitary-adrenal function in patients with corticotropin hypersecretion. Journal of Endocrinological Investigation $1990 \quad 13$ 257-261.

34 Benker G, Hackenberg K, Hamburger B \& Reinwein D. Effects of growth hormone release-inhibiting hormone and bromocriptine (CB 154) in states of abnormal pituitary-adrenal function. Clinical Endocrinology 19765 187-190.

35 Fehm HL, Voigt KH, Lang R, Beinert KE, Raptis S \& Pfeiffer EF. Somatostatin: a potent inhibitor of ACTH-hypersecretion in adrenal insufficiency. Klinische Wochenschrift $1976 \mathbf{5 4} 173-175$.

36 Suda T, Tomori N, Tozawa F, Demura H \& Shizume K. Effects of corticotropin-releasing factor and other materials on adrenocorticotropin secretion from pituitary glands of patients with Cushing's disease in vitro. Journal of Clinical Endocrinology and Metabolism 198459 840-845.

37 Spada A, Reza-Elahi F, Lania A, Bassetti M \& Atti E. Inhibition of basal and corticotropin-releasing hormone-stimulated adenylate cyclase activity and cytosolic $\mathrm{Ca}^{2+}$ levels by somatostatin in human corticotropin-secreting pituitary adenomas. Journal of Clinical Endocrinology and Metabolism $1990 \quad \mathbf{7 0}$ $1262-1268$.

38 Shibasaki T, Nakahara M, Shizume K, Kiyosawa Y, Suda T, Demura H, Kuwayama A, Kageyama N, Benoit R \& Ling N. Pituitary adenomas that caused Cushing's disease or Nelson's syndrome are not responsive to ovine corticotropin-releasing factor in vitro. Journal of Clinical Endocrinology and Metabolism 198356 414-416.

39 Schonbrunn A. Glucocorticoids down-regulate somatostatin receptors on pituitary cells in culture. Endocrinology 1982110 $1147-1154$.

40 O'Carroll AM \& Krempels K. Widespread distribution of somatostatin receptor messenger ribonucleic acids in rat pituitary. Endocrinology $19951365224-5227$.

41 Greenman Y \& Melmed S. Heterogeneous expression of two somatostatin receptor subtypes in pituitary tumors. Journal of Clinical Endocrinology and Metabolism $1994 \mathbf{7 8} 398-403$.

42 Nielsen S, Mellemkjaer S, Rasmussen LM, Ledet T, Olsen N, Bojsen-Moller M, Astrup J, Weeke J \& Jorgensen JO. Expression of somatostatin receptors on human pituitary adenomas in vivo and ex vivo. Journal of Endocrinological Investigation $2001 \mathbf{2 4}$ $430-437$

43 Cervia D, Nunn C, Fehlmann D, Langenegger D, Schuepbach E \& Hoyer D. Pharmacological characterisation of native somatostatin receptors in AtT-20 mouse tumour corticotrophs. British Journal of Pharmacology 2003139 109-121.

44 Strowski MZ, Dashkevicz MP, Parmar RM, Wilkinson H, Kohler M, Schaeffer JM \& Blake AD. Somatostatin receptor subtypes 2 and 5 inhibit corticotropin-releasing hormone-stimulated adrenocorticotropin secretion from AtT-20 cells. Neuroendocrinology $200275339-346$.

45 George SR, Kovacs K, Asa SL, Horvath E, Cross EG \& Burrow GN. Effect of SMS 201-995, a long-acting somatostatin analogue, on the secretion and morphology of a pituitary growth hormone cell adenoma. Clinical Endocrinology 198726 395-405.

46 Lamberts SW, Verleun T, Hofland L \& Del Pozo E. A comparison between the effects of SMS 201-995, bromocriptine and a combination of both drugs on hormone release by the cultured pituitary tumour cells of acromegalic patients. Clinical Endocrinology 1987 $2711-23$.

47 Strowski MZ, Kohler M, Chen HY, Trumbauer ME, Li Z, Szalkowski D, Gopal-Truter S, Fisher JK, Schaeffer JM, Blake AD, Zhang BB \& Wilkinson HA. Somatostatin receptor subtype 5 regulates insulin secretion and glucose homeostasis. Molecular Endocrinology 200317 93-106.

48 Reisine T. Somatostatin desensitization: loss of the ability of somatostatin to inhibit cyclic AMP accumulation and adrenocorticotropin hormone release. Journal of Pharmacology and Experimental Therapeutics 1984229 14-20.

49 Reisine TD \& Takahashi JS. Somatostatin pretreatment desensitizes somatostatin receptors linked to adenylate cyclase and facilitates the stimulation of cyclic adenosine $3^{\prime}, 5^{\prime}$-monophosphate accumulation in anterior pituitary tumor cells. Journal of Neuroscience $19844812-819$.

50 Heisler S \& Srikant CB. Somatostatin-14 and somatostatin-28 pretreatment down-regulate somatostatin-14 receptors and have biphasic effects on forskolin-stimulated cyclic adenosine, $3^{\prime}, 5^{\prime}$-monophosphate synthesis and adrenocorticotropin secretion in mouse anterior pituitary tumor cells. Endocrinology 1985117 $217-225$.

51 Stroh T, Jackson AC, Sarret P, Dal Farra C, Vincent JP, Kreienkamp HJ. Mazella J \& Beaudet A. Intracellular dynamics of sst5 receptors in transfected COS-7 cells: maintenance of cell surface receptors during ligand-induced endocytosis. Endocrinology $2000141354-365$.

Received 30 September 2004

Accepted 14 December 2004 